\title{
Imperatives of Commodities Stockpiling in Nigeria
}

\author{
Ogunwusi A. A. Ibrahim H. D. \\ Raw Materials Research and Development Council, Abuja
}

\section{DOI: $10.7176 / \mathrm{JRDM} / 52-04$ \\ Introduction}

Nigeria's development has always hinged on its natural resources. The level of exploitation and degree of development of the resources have been playing and may likely to continue to play a central role in the economic, industrial and food security status and the wellbeing of the nation (Aribisala, 1993). Prior to independence, Nigeria depends on its forest resources for perspective planning for economic development. As far back as 1899, the perspective planning for economic development was to exploit the forest resources (Adeyoju, 1975). The export revenue from forestry grows at $1 \%, 8 \%$ and $28.8 \%$ between $1950-1960,1960-1970$ and $1970-1980$ respectively (Aribisala, 1993). At the time of independence, Nigeria depended on export of agricultural products such as cocoa, cotton, groundnut, palm oil, palm kernel, various timber species, hides and skin, processed tin ore for its foreign exchange. The development of these resources was vigorously pursued by the British trading firms and this increased agricultural production and productivity, enthrone sustainable forest resources management principles and ensure optimal mineral development practices in order to aid optimisation of export of these commodities. In the minerals sector, minerals such as tin, columbite, and coal constitute major exported commodities and intensification of exploitation activities led to discovery of oil in the 1950's and its exploitation from Oloibiri, Rivers State in 1956.

The high price commanded by oil compared to other commodities in the international market brought oil to the forefront of exported commodities, and turned farming and related activities into lacklustre activities. The petrodollars led to initiation of policies such as import substitution through the First National Development Plan, 1962 - 1968; and in 1970 - 1974; the Second Development Plan which highlighted the weakness of the import substitution strategy such as limited markets which do not allow for spread of industries, nor-allow for intermediate or capital funds (Aribisala, 1993). These made government to shift policy forms to public sector led industrialisation, and, the establishment of big linkage industries such as Pulp and Paper Mills, Fertilizer Plants, Salt Refinery, etc. Although, these postponed the restructuring and transformation necessary to make the Nigerian economy self-reliant and self-sustaining, it created the impetus for local sourcing of industrial inputs. The road to focus on the development of local industrial raw materials became imperative due to the vagaries in oil prices as the low price of oil in the international markets make importation of finished and semi-finished raw materials too expensive to the industrialisation strategy and forced the closure of many industries. Since 1980's to the present, the nation has tossed with a privatisation scheme and a holistic programme for the development of local raw materials for use in the manufacturing sector of the economy. These led to establishment of government agencies such as the Raw Materials Research and Development Council in 1987 and a host of others. It is imperative to stress that the dependence of the nation on commodity export and industrial processing has had its toll on optimal resource availability locally. Despite government's effort to promote industrial utilisation of locally available raw materials and the establishment of a number of presidential committees for commodities development, capacity utilisation is still low across most industries. Likewise efforts being made to promote food availability, economic and physical access to food are still facing several constraints, making it mandatory to put in place strategies that would promote improved capacity utilisation in the industries and to enhance food availability in the country.

One of the major efforts of the present administration to promote commodities availability and industrial use locally is the Anchor Borrowers Programme (ABP) whose major purpose is to create a linkage between companies involved in the processing of selected key agricultural commodities and smallholder farmers. The focus of ABP is to provide seed to farmers and cash to grow the crops in order to boost production of selected commodities in order to promote constant supply of the commodities to the agro processors (Ibirogba, 2018). The projected crops are cereals such as rice, maize and wheat; root and tubers such as cassava, potatoes, ginger and yam; tree crops such as oil palm, cocoa and rubber; legumes such as soyabean, sesame and cowpea; livestock such as fish, poultry and ruminants and cotton, sugarcane and tomato (Ibirogba, 2018). It is expected that this initiative will lead to increased production of agricultural commodities in years to come. One of the major ways the benefit of this initiative can realised is to stockpile some of the commodities to enhance access of industries to them reduce propensity for their export for immediate cash by farmers and to eliminate the possibility of importation at higher prices due to inflation and scarcity as occurred in the global market between 2007 - 2008 (Deuss, 2014). This initiative is not only relevant to agricultural commodities, it is also important for mineral resources development. As at present, more than 30 minerals have been identified as occurring in Nigeria while more than 10 agricultural commodities are currently used in the industrial sector of the country. Some of these also constitute staple foods for the majority of the populace. Thus, conflicting demand for use as industrial raw materials and as staples has 
led to scarcity of some of the commodities for use at industrial scale in Nigeria. As a result, it is imperative to outline strategies that will mitigate conflict in these areas. The primary objective of this study is to identify the need for strategic and or economic stockpiling of the raw materials required for industrial use and for food security purposes in Nigeria. The study also examine the need for stockpiling policy in Nigeria and the potential commodities that may be addressed by such initiative based availability and demand indicators in the country. The type of stockpiles required locally and the quantum of the stockpiles based projected demand and available statistics are also examined.

\section{Objectives and Importance of stockpiling}

Stockpiles are defined as a supply stored for future use, usually carefully accrued and maintained for future use. Thus, stockpiling is the activity of accruing and storing a large quantity of materials (Collins English Dictionary, 2014). The objective of raw material stockpiling is purely economic and is deemed to be the provision of an alternative supply source in the event of a short-term or medium-term supply disruption, rather than counteracting more permanent market imbalances. The term is used in various fields and disciplines to avert the incidence of scarcity. It has been applied in building and roadwork construction (Al Bawaba, 2017), medicine (Sutton and Tierney, 2006), business development (Crusthinger, 2015); in war situations for weapons development materials (IAEA, 2014), Food and Water Emergence Preparedness (APHA, 2018) and in a host of other human endeavours where distortions in supply may cause downtime and social unrests. The focus of a stockpile is to address physical supply shortages (and concomitant price increase) rather than solely on price manipulation. Among the potentials are protection against future supply shortages; protection against price increase, support for companies' longerterm planning and buying time for companies to substitute critical materials; and support for responding to shortterm spikes in demand for specialist materials.

\section{History of minerals stockpiling}

The book managing materials for a twenty first century military by the National Research Council (2008) gave a detailed information of the history of stockpiling in the United States of America (USA) since 1939 by the National Defence Council. Morgan (1949) noted that by 1917, the government of the United States of America (USA) observed deficiency in the availability of specific minerals of great importance, especially during wartime. This led to accumulation of reserve of the minerals. The many supply shortages of strategic materials encountered in World War 1 caused the War Industries Board to recommend that future materials problems should be anticipated and ameliorated (Morgan 1993). Thus in 1922, Army and Navy Munitions Board was established in the war department to plan for industrial mobilisation and procurement of munitions and supplies. The pre-World War II list of important materials was divided into two groups; 14 strategic materials essential to the national defence, the supply of which in war must be based entirely or in substantial part on sources outside the US and 15 critical materials essential to national defence procurement of which in war would be less difficult (for example would be readily available domestically) more than strategic materials (Morgan, 1949). From 1938 through World War II, the first activity to develop an inventory of strategic and critical raw materials was developed and authorised in the Naval Appropriation Act of 1938 which also provided funds to buy strategic items. However, todays NDS had its beginning with the passage of the 1939 Strategic Material Act, which authorized $\$ 100$ million for the Secretaries of War and the Navy, acting jointly with the Secretary of Interior and in conjunction with the Army and the Navy Munitions Board to purchase raw materials for a stockpile. By May, 1940, small quantities of certain materials such as chromite, manganese, rubber and tin were procured under the Strategic Materials Act. By October 1940, both the Army and Navy Munitions Board and the National Defence Advisory Commission, a Presidential Advisory Group had recommended specific quantities of strategic minerals for stockpiling, although not all were procured as a result of fund appropriation (House of Representatives, 1994).

In the post-World War II era to 1958, the stockpile and critical materials Stockpiling Act of 1946 (Public Law 520 - 79) was passed. The National Security Act of 1947 created a Civilian Mobilization Agency, the National Security Resources Board to advice the President. By 1948, the Munitions Board has developed a list of 51 required and critical materials group estimated to have a value of $\$ 2.1$ billion. By 1950 the number of required strategic and critical materials had expanded to 54 groups value at $\$ 4.0$ billion (Snyder, 1966). These requirements were identified based on the updated planning requirements for a 5 year conventional war and also materials for civilian use. These materials were released as required for both military and civilian uses as by different Presidential orders (Snyder 1966; Gutchess, 1969; Kulig, 1992).

The stockpiling history has undergone a variety of changes as dictated by the present world order and a number of countries have devised various methods and reasons for stockpiling various resources. A lot of other changes and scenario are occurring globally with respect to stockpiles of both minerals and agricultural commodities in several other countries to provide safety nets for industrial development and food security especially, in highly populated countries such as China, India, Korea and some developing countries.

Today, the effect of diminishing returns of mining on the world economy is an object of debate (Bardi et al., 
2016). Human ingenuity and market forces are often seen as being able to counteract physical depletion and hence able to maintain an increasing supply of mineral commodities to the world economy. However, a number of observations indicated that depletion is starting to become an important problem in the world economy as growth trends have been slowing down (Brown et al., 2013). Also during the past decade, the minerals commodity market has been showing a robust trend of price increases, even though associated with oscillations and by reverse trend in recent times (Jacks, 2013). In addition, the growth of the world's economy is slowing down; even, for the case of the emerging Chinese economy (Popescue and Nica, 2014). The same kind of slowdown is taking place for world trade (Constantinescu et al., 2015). The limit to growth (Meadows et al., 2004) which project a decline of the world economy as a result of the increasing cost of mineral production which is reflected on the financial system with pauperisation of a large fraction of the consumers which depresses demand. Depletion may also exacerbate the problem that many critical elements which are essential for high tech application come from regions which are politically and economically unstable and show high rates of corruption (Jakobi, 2014). In addition to this, supply shocks have already been observed in the past for some specific commodities, such as for crude oil in the oil shock of the 1970's and for rear earth in recent years (Areddy, 2011). It is possible that new shocks will be observed in the future as depletion becomes a more important problem, most especially for rare and expensive minerals used in the electronics industry (Jakobi, 2011). One possible reaction of the economy and the industrial system to these problems may consist in stockpiling resources, keeping them readily available in order to ensure supply in any moment (Ugo Bardi et al., 2016). Some countries also manage their resources in such a way to lengthen their duration which is typical of government which may act on the basis of long term strategic considerations (Ugo Bardi et al., 2016). This may occur in the case of rare earths. As China alone produces more that $90 \%$ of the world's rare earth supply (Stephenson, 2013), the Chinese may totally dominate the marketing rate of a the mineral resource (Ugo Bardi, 2016). China was accused to have implemented rare earth embargo in 2010 in order to raise the price of the resource (Areddy, 2011), thereby confirming the need for stockpile of critical and strategic commodities of high industrial requirement.

\section{Stockpiling of Agricultural Commodities and Food Items}

Stockpiling of agricultural commodities has also received significant attention overtime across the globe. In the United States of America, the Agricultural Trade Development and Assistance Act of 1954 (Public Law 480, 83 ${ }^{\text {rd }}$ Cong.), of which Title I provided for the creation of a supplemental stockpile of strategic and critical materials; and title III provided for barter of agricultural commodities for strategic materials which entail less risk from deterioration and spoilage, as well as substantially less storage cost are cases to buttress this. The Agricultural Act of 1956 (Public Law 540, 84th Cong.), Section 206, further facilitated barter of surplus agricultural commodities by stipulating that materials acquired by barter in excess of the needs of other programs should be transferred to the supplemental stockpile. The need to ensure the stability in terms of availability, access and utilization of food has long been a central concern for national governments, and more recently, global multilateral institutions concerned with food and agriculture.

Many paths to ensure food stability for countries are being employed globally. International food markets and trade have been considered as one of the most efficient ways for centuries. Similarly, pursuing self-sufficiency policies and ensuring the production of all required food within the country has been another strategy of choice. However, neither has proved to be successful or efficient, all of the time, in the past. Of late, especially in the aftermath of the world food (price) crisis in 2007/2008 and 2011 when the international food markets were extremely volatile, governments have been revisiting one of the oldest strategies to ensure greater stability - that of maintaining food stockpiles. In recent times, public stockpiling has gained interest and is fast becoming an option in national food policies. This method is being applied in countries like India, China, and Indonesia, and among countries that rely heavily on food imports, such as the United Arab Emirates (UAE), Bangladesh, the Philippines, and Malaysia among others. In the Asian region, the resurgence is observed especially after the experiences of India and Vietnam banning exports of rice and grains in 2007/08, and Russia's ban on wheat exports in 2010. Maintaining stockpiles is now largely viewed as a response to international trade uncertainties and volatility. Unlike minerals exploration, some of the characteristics of agricultural raw materials production are their seasonality and abundant availability during season and their low shelf life. In less developed parts of the world, storage facilities are scarce and in most cases non-existent in most rural farming communities. These made farmers to sell of most of their produce after harvest at low prices and without much gain as losses of between 30 $-70 \%$ have been recorded in a number of cases. To mitigate this development, governments across the world have been involved at one time or the other on stockpiling of food staples in an attempt to contain panic buying, inflation and social unrest. This however may drive agricultural commodity prices higher. The cost of the world's most important staple reached high levels in 2011 after countries from Algeria to Saudi Arabia announced extraordinary purchases (Financial Times, 2011). Stockpile of agricultural commodities by China is also increasing on annual basis (Financial Times, 2015). Chinese Government buying off cotton, wheat, corn, soya, sugar and rice above market prices has encouraged China to grow strategic crops (Financial Times, 2015). As at 
February 2015 , China had stockpiled $60 \%$ of the world cotton stocks. The bigger the stockpiles grow, the harder it is for Beijing to extricate itself without dumping the glut into the market and the move will reverberate into international markets as China has become a larger buyer of agricultural commodities (Financial Times, 2015). Chinese policy makers fear that releasing its inventories would depress prices and push farmers towards more lucrative crops, ultimately increasing China's reliance on import (Financial Times, 2015). China's grain harvest has risen every year for more than a decade as high prices has encouraged farmers to grow strategic crops. However costs have remained high and agricultural sector is uncompetitive compared with other countries. Kurns (2018) indicated that another issue is the oversupply of commodities that China is stockpiling. The report observed that by $2^{\text {nd }}$ quarter of 2018 , China has $47 \%$ of the world's residual supply of wheat, $40 \%$ of the world's residual supply of corn, $66 \%$ of rice, $46 \%$ of cotton and $22 \%$ of the residual supply of soybeans.

In Africa, the situation is not drastically different as a number of countries are also planning to increase strategic food reserve. Kenya government planned to increase its strategic food reserve to eight million bags of maize in the medium term to boost food security in the country. Wamalwa (2018) indicated that 14 million dollars was set aside in the financial year to purchase maize both locally and abroad to boost food reserve as the then current stock level of three million bags of the staple crop was observed not to be sufficient buffer stock in case of a drought or pest or high international price of maize. In the country, the biggest threats facing maize production were drought and fall army worms. Data from the Ministry of Agriculture indicated that the country produces approximately 39 million bags of maize annually, against a consumption of 46 million bags. The shortfall is met through imports from international markets as well as through informal trade from Uganda and Tanzania. To guarantee more maize production, government planned to enhance investment in irrigation as well as fertilizer and subsidies to maize farmers. Wamalwa (2018) also observed that over-dependence on a single crop makes the country vulnerable to food shortages and that the country is also promoting production of potatoes and indigenous cereals such as sorghum and millet that are more resilient to drought conditions. Also, Kenya considered putting in place a policy to enhance investment in Arid and Semi-Arid Land (ASALs) areas to promote inclusive growth. As a result, a multisectoral taskforce was appointed to develop the policy that will guide investments into the remote areas (Wamalwa, 2018). The policy was expected to coordinate national, country government and donor funding efforts in the ASALs regions that account for more than 70 per cent of the country's land mass. The policy would provide a framework to align ASALs development plans and priorities to the national development blueprints Vision 2030, the third medium term plan, the UN Sustainable Development Goals, as well as the government's development blueprint (Wamalwa, 2018). Although, the areas have received limited government support as they were considered unproductive regions, government's plan was to ensure no region is left behind in order to promote equitable development across the country (Briones, 2014).

\section{Recent Stockpiling Practices}

In view of its increasing importance to sustainable development, a number of countries have latched on the stockpiling policy phenomenon to ensure food security, industrial development and production of strategic commodities. Southeast Asia hosts some of the world's largest producers and consumers of rice; a key grain staple in Asia. Some of the largest exporters in the world are in the region, namely Thailand and Vietnam; likewise some of the largest importers, namely Indonesia and the Philippines. Malaysia is also a significant importer. Brunei and Singapore, the two high income economies, rely almost entirely on imports (but are small players in the market). The Association of Southeast Asian Nations (ASEAN), together with the Plus Three countries, namely China, Japan, and Republic of Korea, have recently established a regional emergency rice reserves. In most Asian countries, under this new approach, public stocks are held as emergency reserves. Releases from public stocks can be triggered by a severe supply contraction and or price increases. To address humanitarian goals, releases may take the form of targeted safety nets. Price stabilization is not a goal of emergency reserves, although sizable and well-timed releases may exert a calming effect on markets and thereby stave off even worse price increases. Such a rationale for public stocks contrasts sharply with traditional public buffer stock schemes.

In 2011, Thailand, government raised the settlement price to about $\$ 500$ per ton of paddy and about $\$ 770$ per ton of the milled equivalent. The prices were above the prevailing Free On Board (FOB) prices, even disregarding processing and marketing costs. The pledging program was transformed into an expensive produce price support scheme. Public stockholding was deployed in service of this scheme. Government stockpiles ballooned, reaching 16.7 million tons in milled equivalent by the of 2013, compared to 7.2 million tons at end-2011, at the start of the new pledging scheme. The program was successful in raising the paddy price; although, Thai rice exports have fallen. Indonesia formulated an explicit state policy on food reserves based on national law. The Food Law of 2012 enacts a system of public food reserves, based on a hierarchy from government food reserve, down to provincial, regency/city, and to village food reserve. The law furthermore mandated that food self-sufficiency be promoted in order to meet food demand. Imports are prohibited except when necessary in case of a shortfall of domestic production and reserves. Unfortunately self-sufficiency provisions in Indonesia (and similar regulations in other countries) suffer from vagueness; after all, when domestic supplies are low, domestic demand can be fit to that 
supply simply by making domestic price sufficiently high. The Food Law does provide for Food Affordability. In fact, the Perum BULOG - a state trading enterprise stockpiled 2 million tons of rice by end the end of 2013 , following government instruction (Briones, 2014).

In Malaysia, the food security argument in favor of public stocks does not necessitate public ownership of stocks. The aim is to reach the desired level by some incentive or regulation scheme (or both) on private stocks. Malaysia is an example of deployment of private stocks, in this case owned by BERNAS, for national food security (Briones, 2014).. The company is under contract with the government to maintain a National Rice Stockpile. The contract confers exclusive import rights to BERNAS, effectively making it a monopoly (though the right can be assigned by BERNAS to other traders). BERNAS views the National Rice Stockpile not only as food security but also for price stabilization. In contrast to Malaysia, Singapore exemplifies the case of full private sector engagement for the food security requirement of the state. Such engagement is enforced by a minimalist regime of market regulation. Singapore imports all its rice requirement; by law, government implements a Rice Stockpile Scheme, which compels importers to store two months' worth of imports in a private warehouse designated by government. The importers continue to own the stocks; however government can acquire the stocks subject to compensation. Importers are also responsible for rotating stocks; any batch of stock may be stored for a maximum of one year.

Among the Southeast Asian countries, the Philippines present a case of effectiveness of public stockholding for price stabilization. In mid-2013, retail price of regular milled rice jumped by $13 \%$ over a span of four months, catching many consumers by surprise, especially since rice prices had remained stable. As a result, the Senate Committee on Food and Agriculture called a series of hearings on the true supply situation for rice in the country. The Secretary of the Department of Agriculture (DA) blamed the spike on an "artificial shortage" caused by some unscrupulous traders or possibly even smugglers. Likewise a nationwide farmer's organization blamed the machinations on cartelization. Empirically however collusion in the rice market has been difficult to establish; all the available evidence points rather to a competitive rice market along the supply chain.

\section{Stockpiling Practices}

In most countries, most stockpile programmes are economic in nature. In most of these cases, strategic stockpiles are mostly held by the government while economic stockpiles may be held by both the public and the government. In most cases, the computation of stockpile objective for any material involve consideration of the duration of emergency, estimated annual requirement during emergency, and estimated year by year supply from other sources other than the stockpile. Apart from stockpile defined as the basis of utilization, these are also three types of stockpiles based on holding authorities. Caballero Anthony et al., 2015 distinguished three types of stockpiles based on holding authorities, most especially when issues of food security is discussed. These include public stockpiles directly owned, monitored and administered by government via State owned enterprises such as Food Corporation of India, Bulog in Indonesia, Bernas in Malaysia and National Food Authority in the Philippines; Private stockpiles which is exclusive to private organistions but can be monitored and co-administered by both private owners and the government. This is an initiative adopted by the Philippines government. In Singapore, government use discretionary power to ensure a minimum quantity of private stockpiles which need to be maintained for a stipulated period of time. In the case of household stockpiles, consumers held stockpiles which are monitored to some extent by government such as in the Philippines. This is also a scarcity reduction measure embarked on in countries prone to disasters such as the earthquake tsunami in Japan where a three day of food and water ration stockpiles are encouraged to enable survivors feed before support from first responders.

In most countries today, four types of public stockpiles are maintained at national or regional levels (Caballero-Anthony et al., 2015). These are Emergency/Humanitarian Stocks which are maintained to protect access to food in the event of food shortage during emergencies. The stocks for food security are used by governments to ensure stability in the availability and price of food. Stocks are used to control domestic supply and price of food. The stocks are bought from farmers and or markets when they are cheap and released when market prices become unaffordable. Safety net stocks target lower income segments of the society. The stocks are sold at highly subsidized prices to people based on a defined poverty line in countries such as India and Indonesia. The stocks for trade are the stocks held by exporting countries that have little urgency in terms of ensuring food availability for its people. The purpose of such stock is to guarantee minimum profit margin for farmers and for export stability. These mostly have to do with essentialities of strategic, economic and food stockpiles. It is however important that a number of stockpiles be maintained by private sector operatives in different fields of endeavor. Some drugs are stockpiled in the medical sector to forestall epidemic, etc., while a number of manufacturing outfits carry out stockpiling intermittently based on their manufacturing schedules to forestall downtime in their activities. Table 1 show selected countries and the types of stockpiles maintained by them. Apart from these, regional stockpiling are also being formulated as a strategy for multi-lateral stockpiling mechanisms. An example of this is the ASEAN Plus Three Emergency Rice Reserve (APTERR) comprising of the ten ASEAN member countries and the World Food Programme (WFP) which is coordinating the UN Humanitarian Response 
Departs, (UNHHRD) to maintain international stockpile which includes medical kits, shelter items and ready to use foods in Ghana, United Arab Emirate, Malaysia, Panama, Italy and Spain.

\section{Prospects for Stockpiling in Nigeria}

Nigeria overtime has reorganised the need for sustainable development of its minerals and agricultural commodities. To promote the development of these, the country has initiated measures that will promote the development of its industrial sector. Nigeria is one of the richest countries in Africa in terms of mineral resources (World Bank, 1984). About 34 minerals have been identified in the country. Nevertheless, the contribution of solid minerals sector to Nigeria economy is less than $1 \%$ (Okechukwu et al., 2009). The development of the sector started to depreciate with the discovery of oil in the 70's (Aribisala, 1993, RMRDC, 2017, RMRDC, 2018). The need to come out of the mono-economic base and diversity the economy has necessitate new initiatives in the solid minerals sector. A number of problems bedevil the minerals sector of Nigeria. Among these are ineffective local capabilities for detailed and scientific exploration and exploitation, paucity of funds for SME's to participate in the exploration of minerals in the country, and the inability of the government corporations to adapt to challenges of new developments with the mining sector (Okechukwu et al., 2009). Other includes lack of local capabilities to manufacture exploration, exploitation and beneficiation facilities and high dependence on imported or locally adapted equipment. Another major problem is inadequate availability of infrastructural facilities such as electricity and road network.

Presently, seven minerals have been designated as strategic in Nigeria. These strategic minerals are limestone, barites, iron, bitumen, lead and zinc. There is plan to ban the importation of these and to encourage local mining and industrial utilisation. In addition to the above, the Federal Government has concluded plans to grant miners in the country a tax holiday as well as offering them duty free importation on all mining equipment. The strategic status of these minerals is based mainly on availability of data around their continued commercial viability. The resources are priorities for Nigeria's domestic industrialisation and infrastructure requirement. The emphasis is to focus on the domestic production of these minerals at a quality level comparable to imported ones for better utilisation potentials in Nigerian and African industry, an approach designed to win market share from imports. In order to ensure sustainable utilisation of the minerals, the country intends to preserve and extend the life of its holdings, for future generations. This will require a careful licensing regime at the MCO that corresponds to the sustainability agenda. The major potential operators/participants would focus on building competitive enabling environment for all entrants. The explicit bias will encourage formalisation of artisanal miners while encouraging a competitive structure industry. The initial customer focus will serve companies and end users that already purchase minerals and process materials from offshore sources. These will include customers in the cement, oil, power and industrial sectors. For example substituting importation of coal with domestically sourced coal would be illustrative of such a step. Stockpile of mineral in Nigeria has to be adequately and well considered as the nation is not under any condition of war. The major consideration that can be applied for stockpiles of mineral resources in Nigeria is economic. This may be done having taken into consideration industrial requirements and to be used as possible sources of income through foreign exchange generation, poverty alleviation and employment generation. The consideration employed in use of the selection of stockpiled minerals include importation in areas where supply problems could arise from insufficient domestic natural resources, inadequate domestic processing facilities, dangerous dependence on vulnerable foreign sources of supply and potential transportation hazards.

For any assessment of minerals to be stockpiled, there is need for knowledgeable people in the materials field to advice. The primary goal of the experts would be to identify those materials which are directly related to the national problems which stockpiling policies are designed to alleviate.

Among the priorities that may be considered for formulation of policies are:

1. Provision of materials for optimal development/capacity utilisation of strategic sectors of the economy in Nigeria;

2. Provide foreign exchange as a means of diversification of exports;

3. Adequacy for improved power generation locally;

4. Importance for the development and sustainable operations of SMEs in Nigeria.

5. Development of new and advance materials

In the case of agricultural commodities, the need for stockpiling had been recognised before now. The nation has an Emergency Management Authority called National Emergency Management Agency (NEMA) and State Emergency Management Agency (SEMA) in all the States and the Federal Capital Territory, FCT, Abuja. The mission of NEMA and SEMA are to coordinate resources towards efficient and effective disaster prevention, preparedness, mitigation and response in Nigeria. The Federal Government allocated 1\% of the GDP and 20\% Ecological Fund to disaster management while others are utilised by the Federal Ministry of Environment, Health and others that contribute to disaster risk reduction and mitigation as well as States and Local Governments of Nigeria (NEMA, 2018). In line with its mandates, NEMA stockpiles relief materials in warehouse at the six zonal offices and the NEMA Headquarters, Abuja. 
In 2014, the Federal Government is planning to concession for a period of 10 years its silos that exist in different parts of the country. Out of the total the government plans to keep six of them for keeping $5 \%$ of all the grains produced on annual basis. The concession will be for likes of Dangote and Cascharis Group for drying and storing their products (Ogbeh, 2018).

The needs for more food stockpiles have become imperative in the country. This is important in view of the various disasters happening within the country. The most important of these natural disasters are caused by climate change which is gradually leading to flooding during the wet season in some parts of the country and drought and desert environment in other parts of the country. Also the need to establish safety of stocks, buffer stocks and emergency stocks for various agricultural commodities are outlined in Table 3 . Presently, the manufacturing sector contributes less than 5\% of the GDP as a result of various problems one of which is unavailability of desired raw materials as at when needed. The manufacturing sector of the Nigerian economy has not recorded significant growth in the last six years, 2010 - 2015. Indications are that the sector is still weak, tepid and remain distressed. This is evident in the trend in key performance indicators such as capacity utilisation and local sourcing of raw materials over the six year period shown in Tables. In spite of expressions of a desire to remove the bottlenecks and stimulate growth in industrial production through increased sourcing of local raw materials, the expected improvement and growth in manufacturing has not been realised as the sector still remain in a distressed situation. As can be seen from Tables, average capacity utilisation over the six year period was 49.73 per cent while local sourcing of raw materials averaged 49.06 per cent over the six year period.

A number of constraints hampered the operations of the industries, leading to gross underutilisation of production capacity. The problem afflicting local sourcing of raw materials are multi-dimensional. There is need for deliberate efforts and sector-specific strategies that must be made to increase the nation's ability to raise the level of local raw materials sourcing. It is curious to note that most of these sectors fall within areas where a substantial proportion of the needs of local industries ought to be satisfied locally. The drive to enhanced local sourcing has continued to be constrained by inadequate technical facilities to process raw materials to the right technical specifications and quality, including uncertainty of supplies arising from irregular production and supply schedules. In view of the importance attached to raising the local content and value-added of local industries, a more decisive effort should be made to remove the constraints to local sourcing of raw materials.

As a result of this, it is incumbent on the government to encourage the private sector to stockpile strategic raw materials in critical industries that relied mostly on importation and where local production is insufficient to meet industrial demand. Table shows the major secondary raw materials required across the ten industrial sectors of the Manufacturers Association of Nigeria. The functionality of the industries within the sectors is based mostly on these raw materials. Adequate availability of these raw materials will provide the necessary stimuli for smooth operation of most of these industries. The case for government support for stockpiles in private sector manufacturing concerns has several justifications. In the wake of the oil glut of the 1980's which led to the collapse of most of the industrial concerns in Nigeria, the major problems faced by the industries were mostly disruptions in raw materials supply. For instance, the two operational pulp and paper mills as at then, the Nigeria Paper Mill (NPM), Jebba and the Nigeria Newsprint Manufacturing Company (NNMC), Oku-Iboku, were closed down due to disruptions in the supply of long fibre pulp (Makinde, 1984; Ogunwusi, 2011: Onwualu, 2010: Osadare and Udohitinah, 1993: RMRDC, 2010; Osadare, 1997). Although, the mills have been privatised since the mid $2007 / 2008$, the NPM mill, Jebba is yet to commence production of virgin pulp for kraft paper production while NNMC is yet to commence production of newsprints (Ogunwusi, 2010; RMRDC, 2016). This is also the situation with a number of other industrial concerns in the country. Economic stockpile involves three basic considerations. The first is the possible national purpose of maintaining productivity and job security even in the face of global disruption in supply or cartelisation; second, the economic trends and cycles anticipated during overall stockpiling operation of buying, holding and selling to achieve the objectives of Nigeria Industrial Growth Plan (NIGP) and the types of benefits and costs which accrue to the country in general as a result of stockpiling. It also helps the private sector organisations to maintain supply under a variety of supply disruptions, for anticipation of price increase and for several other reasons. For the success of private sector stockpiling by manufacturing companies, government can offer incentives to ensure compliance. In addition, government should have an effective way of monitoring compliance to such policy/initiative.

\section{Prospects for Strategic and Economic Stockpiling in Nigeria}

Government has already put in place policies for improved agricultural production and productivity in Nigeria. These include the Agricultural Transformation Agenda, the Anchor Borrowers Programme and a host of others. In addition, there are also various commodities development programmes initiated and currently operating locally. The vision of these policies is to achieve hunger free Nigeria through an agricultural sector that drives income growth, accelerate achievement of food and nutritional security, generate employment and transform Nigeria into a leading player in the global food markets to grow wealth for millions of Nigerian farmers (Mbah and Igbokwe, 2014). The mandate of the Agricultural Transformation Agenda is to fast track the positive transformation of the 
agricultural sector in order to increase the quantity and quality of agricultural products. According to Akinwumi (2012), as part of the Federal Government effort to revamp the agricultural sector, ensure food security, diversify the economy and enhance foreign exchange earnings, the FMARD embanked on the transformation agenda with a focus on development of agricultural value chains, including the provision and availability of improved inputs (Seeds and Fertilizer), improved productivity as well as establishment of staple crop processing zones. It also addresses the reduction in post-harvest losses, improve linkages with industries, with respect to backward integration as well as access to financial services and markets. To boost achievement under the Agricultural Transformation Agenda, the Government also introduce the Agricultural Promotion Policy (2016 - 2020) to refresh the transformation agenda in order to provide disciplined approach to building an agribusiness ecosystem that will solve the twin problems of low productivity and high exchange expenditure on food imports using the private sector led approach. It is apparent that this approaches have led to increase in production of a minor of commodities, most especially rice production. The production increased from 5.5 million tonnes in 2015 to 5.8 million tonnes in 2017 although the consumption rate has also increased to 7. 9 million tonnes (Goroyo, 2017). The Anchor Borrowers Policy under which this initiative took place has also created an economic linkage between small holder farmers and reputable large scale processors, thereby increasing agricultural outputs and significantly improving capacity utilisation. Also the Fertilizer Initiative launched by the government in December 2016 as the outcome of the partnership between the governments of Nigeria and Morocco and implemented as a Public-Private Partnership is on stream, while the Presidential Economic Diversification Initiative (PEDI) which support the revival of moribund industries by facilitating new investment, bottlenecks and enabling access to credit has made breakthroughs in the agricbusiness sector in Imo and Ondo States (Toromade, 2018).

In the minerals sector, the government has recognised the need for improvement and a number of improvements are already taking place in the sector. Although, the sector is still largely underdeveloped despite its glorious past and abundant mineral resources for development, it is expected that with government present initiative, it will peak up. The decade of reforms has led to passage of a new Nigeria Minerals Mining Act (2007), a Nigeria Mineral and Metal Policy (2008), the creation of a Modern Mining Cadastral System, the requirement of the tax code, and the expansion of airborne mapping of the country to sharpen knowledge of minerals endowment (Ministry of Mines and Steel Development, 2018). Despite these, investors perception is still not favourable for the sector as a result of undue interference by communities and State governments.

Nevertheless, a stockpile policy by the Federal and State governments will boost productivity within this sector as miners will be assured of outlet for mined minerals and cooperation of the State governments. Based on the opportunities provided by the initiative, the barriers militating against the sector such as geosciences data and other information, participation by industries and other stakeholders can be improved on. This will also address one of the major setbacks in the sector which is lack of confidence in domestic users of industrial minerals. It will also provide opportunity and basis for Nigeria to return to the global ore and mineral markets at a market competition point. Large part of the global private sector continues to rely on natural resources either as part of companies core business, or in their supply chain. The readiness of government to support the stockpiling of economic and critical raw materials through incentive, will lead to increased capacity utilisation in most of the companies. A key mechanism for economic growth is higher productivity and knowledge transfer and the private sector can be a critical facilitator of this process. Private firms and entrepreneurs invest in new ideas and new production facilities.

\section{Challenges of stockpiling Policy in Nigeria}

One of the major challenges will be to decide on whether to have a centralised stockpile, decentralised stockpile or a combination of both. Also managing stockpiles has a cost to it and having excess levels of stockpiles will negate the benefits. In addition, one of the biggest challenges with stockpiles is the measurement of quantity and quality parameters, most especially as relates to minerals stockpile. Accuracy in measurement is a challenge as stockpiles are usually several feet high and widely spread. Although, laser based measurement and use of advanced technology such as drones to take aerial photographs are possible, these, will increase cost. Added to this, mineral stockpiles often undergo changes in their composition as weather conditions vary.

In the agricultural sector, most especially as regards food stockpiling, these are many examples in the past where public stockpiling programme have failed to achieve their goals and have ended up burdening tax-payers and the economy (Caballero-Anthony et al., 2015). It can also led to a net negative at international level. Stockpiling policies need to be clear in terms of rationale, goals and objectives. Also the possibility of using stockpiles for political gains in Nigeria by politicians is real. The Food Security Council inaugurated in March 6,2018 should look at the option of food stockpile as a way of promoting and harnessing the success of the various Agricultural Development initiations.

\section{Conclusion}

The need for a stockpile policy has become imperative in view of its various strategic and economic advantages. 
However, there is need for government to critically carry along the States and LGA for this initiative to be a success locally.

\section{References}

Adeyoju, S. K. (1975). Forestry and the Nigerian Economy. Ibadan University Press, Nigeria, 308pp.

Aribisala, A. O. (1993): Raw Materials Revolution and Impact on Industrialisation in Nigeria. Mednet Publications Ltd. (1993). ISBN 978 - 024 - 000 - 4

Akinwumi, A. (2012). Federal Government Initiates Agricultural Transformation Agenda to Boost Economy. Blueprint Newspaper, Pg. 3.

Al Bawaba (2017). Roadwork- Production and Stockpiling of Aggregate for a Total of 16 Stockpiles. The Free Library 2018. Syndicate Media $\quad$ Inc. $01 \quad$ Sep:2018. http://www.thefreelibrary.com/Roadwork+ production+Ane+Stockpiling $+01+$ Aggregate + for + A + ttotal $+01+$ $16+\mathrm{a} 0521718580$.

Areddy, J. T. (2011). China Moves to Strengthen Grip over Supply of Rare-earth Metals. http://www.wsj.com/articles/SB10001424052748704124504576117511251161274.

Bardi, U. and Caporali, S. (2016). Precious Metals in Automotive Technology: An Unsolvable Depletion Problem? Minerals 4:388-398. doi:10.3390/min4020388.

Adeyoju, S. K. (1975). Forestry and the Nigerian Economy. Ibadan University Press, Nigeria, 308pp.

Aribisala, A. O. (1993): Raw Materials Revolution and Impact on Industrialisation in Nigeria. Mednet Publications Ltd. (1993). ISBN 978 - 024 - 000 - 4

Briones, R. M. (2014). Public Stockpiling in Southeast Asia: Review and Prospects. FAO Publication

Brown, T. J; Shaw, R. A; Bide, T; Petavratzi. T; Raycraft, E. R; Walters, S. A. (2013). World Mineral Production 2007 - 2011. Keyworth, Nottingham.

Caballero-Anthony, M; Paul, P. S. T; Shrestha, M; Tamara, N; and Jonatan, A. L. (2015). Public Stockpiling and Food Security, Policy Brief. RSIS. Nayang Technological University.

Collins English Dictionary (2014). Complete and Unabridged $12^{\text {th }}$ Edition Harper Collins Publishers, (1991, 1994, 1998, 2000, 2003, 2006, 2007, 2009, 2011 and 2014).

Constantinescu, C; Mattoo, A; Ruta. M. (2015). The Global Trade Slowdown: Cyclical or Structural? IMF Working Paper. https://www.imf.org/external/pubs/ft/wp/2015/wp1506.pdf. Accessed 7 Mar 2016.

Deuss, A. (2014). Review of Stockpiling Policies: Better Policies for Better Life. Paper Prepared as a Background Document for the OECD Global Force on Agriculture. Issues in Agricultural Trade Policy. 2 December, 2014. Paris.

Goroyo, S. (2017). Rice Production in Nigeria Increases to 58 Million Tonnes in 2017 - RITAN. Punch, $17^{\text {th }}$ May, 2017.

Gutchess, F.J. 1969. Selling Defense Material- An Informal Historical Compilation of the Program for the Sale of Excess Strategic and Critical Materials by the General Services Administration, Property Management and Disposal Services Through June 20, 1966.

House of Representatives (1994). House of Representatives Readiness Subcommittee of the House Armed Services Committee, 1994. Prepared Statement of Alfred R. Green wood, Congessional Research Service before the Readiness Committee on Issues Relating to the National Defence Stockpile, March 8.

http://www.greensolutionsmag.com/?p=1750

IAEA (2014) IAEA Says Irans 20\% Stock is down by 18\%. The Free Library 2014. Ivan Times International 01 Sept 2018 https://www.the freelibrary.com/IAEA+says+iran\% 27s+20\%25+stock+is+down+18\% 250362853742 .

Ibirogba, F. (2018). Taking Advantage or Off-taking, Anchor Borrowing Agric Schemes. The Guardian Business Agro. 27 $7^{\text {th }}$ August; 2018.

Jacks, D. S. (2013). From Boom to Bust: A Typology of Real Commodity Prices in the Long Run (No. 18874) doi:10.3386/w18874.

Kulig, J. W. (1992). The National Defense Stockpile. In SMS Mining Engineering Handbook. H. L.Hartman, A. B.Cummins, and I.A. Given, eds. Littleton, Colo: Society for Mining Metallurgy.

Makinde, M.A. (2004): Keynote Address at the National Symposium of Technical Association of Pulp and Paper Industry in Nigeria. In Proceedings of National Symposium on Rehabilitation of the Forestry, Pulp, Paper and Board Industries for the Revival of National Economy. March, 2004.

Ministry of Mines and Steel Development (2018). Roadmap. www.mineand steel.gov.ng.

Morgan, John Davis, Jr. (1949). The Domestic Mining Industry of the United States in World War II: A Critical Study of the Economic Mobilization of the Mineral Base of National Power.

Morgan, John Davis, Jr. (1993). Strategic Materials: Government's Role. Forum for Applied Research and Public Policy 8(3):97-100.

National Research Council (2008). Managing Materials for a Twenty First Century Military Washington DC the 
National Academy Press. http://doi.org/10.17226/12028

NEMA (2018). National Emergency Management Agency (Nigeria) http://www.nema.gov.ng|Nigerian Minerals and Metals Policy (2007)

Ogbeh, A. (2018). FG to Generate $¥ 6$ b from Concession of 20 Silos. Infrastructure Concession Requlatory Commission. The Presidency. https://dailytimes.ng/fg-generate-n6bn-concession-20-silos/

Ogunwusi, A.A. (2011). Pulp and Paper Industry in Nigeria: Current Status, Challenges and Options for Resuscitation. Nig. Jour. of For. 41(1): 6-16. (Nigeria)

Ogunwusi, A.A. (2013). Impact of privatisation of primary pulp and paper mills on performance of the pulp and paper sector in Nigeria. Developing Country Studies.3(7):109-119.

Okechukwa, I. N.; Musa, M; Ashiru, M. A. and Dada, G. I. (2009). Strategies, Prospects and Constraints of Solid Minerals Development in Nigeria. Nig. Jour. Res. Produce. 15(21:1-9).

Onwualu, A.P. (2010): Pulp and Paper Sector in Nigeria: Challenges and Prospects. Paper Presented at the Annual General Meeting (AGM) of the Pulp, Paper, Paper products, Printing and Publishing sector. MAN House, Lagos. July, 2010.

Osadare O.A. (1997):. Strategies For Long Fibre Pulp Production In Nigeria. Nig. Jour. For. 24(1 and 2). pp 1620

Osadare, O. A. and Udohitinah, J.S. (1993). Fiber characteristics of some Nigerian raw materials for long fibre pulp production. In Forestry urbam and rural development in Nigeria. E. A. Oduwaiye ed. Proceedings of 23rd Annual Conference of Association of Nigeria, Ikeja, Lagos State pp 133-138.

Popescu. G; Nica, E. (2014). The Roots of China’s Economic Slowdown. Knowl Horizons-Econ 6:14-17.

Snyder, D. H. (1966). Stockpiling Strategic Materials, Politics and National Defense. San Francisco, Calif.: C.A. Chandler Publishing.

Stephenson. K. (2013). Recycling Rare Earth Minerals.

Sutton, J. and Tierney, K. (2006). Disaster Preparedness; Concept and Guidance and Research. Fritz Institute. Ass Disaster Preparedness Conference 2006 Nov. 3 - 4, Sebastopol, CA, USA; 2006 http//www. Fritzinstitute org/pafs/whitepaper/disasterpreparedness concept paf.

Toromade, S, (2018). 5 Agricultural Initiatives by Present Administration He want you to know about. Pulse.ng $25^{\text {th }}$ April, 2018.

Ugo Bardi; Rolf Jakobi and Hiroshan, H. (2016). Biophys Econ. Resource. Qual 2016:1:4. DOI 10: 1007/s 41247016-0004X.

Walmawa, M. (2018). Kenya Increases Strategic Food Reserve Pm. News: http://www.msn.com/en$\mathrm{xl} /$ africa/top/stories/Kenya-increases-strategic-food-reserve/.

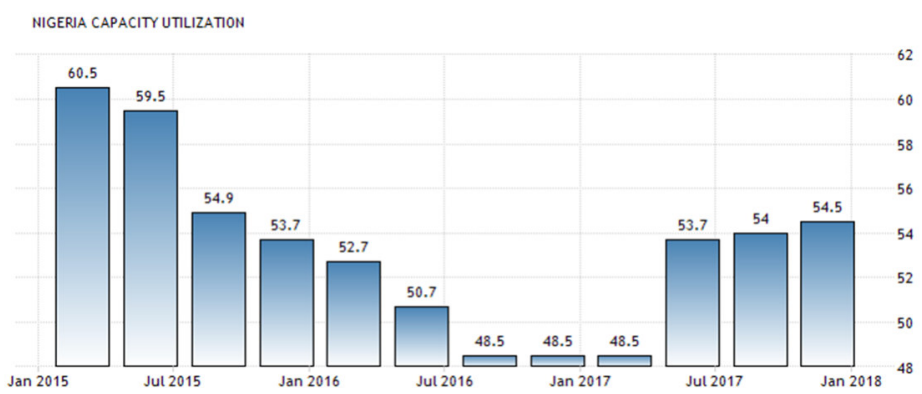

Fig.1 Nigeria Capacity Utilization 2015-2018 
Table 1: Gaps in Demand and Supply across Key Crops and Activities (2016 estimates)

\begin{tabular}{|c|c|c|c|}
\hline Crop & Demand (tons) & $\begin{array}{l}\text { Supply } \\
\text { (tons) }\end{array}$ & Observation \\
\hline Rice & 6.3 million & 2.3 million & Insufficient supply chain integration remains issue. \\
\hline Wheat & 4.7 million & 0.06 million & $\begin{array}{l}\text { Driven by demand for various types of wheat (white, hard, } \\
\text { durum), etc. for bread, biscuits and semovita. }\end{array}$ \\
\hline Maize/Corn & 7.5 million & 7.0 million & $\begin{array}{l}\text { Limited imports required buy can shift due to feed } \\
\text { demand }\end{array}$ \\
\hline Soya Beans & 0.75 million & 0.6 million & Animal feed and protein cost alt. driving demand. \\
\hline Chickens & 200 million birds & 140 million & $\begin{array}{l}\text { Gap filled by illegal imports that enter market at lower } \\
\text { price point than domestic producers; gap also a moving } \\
\text { target based on fast food/QSR demand. }\end{array}$ \\
\hline Fish & 2.7 million & 0.8 million & $\begin{array}{l}\text { Fall off in ocean catch and weakness in aquaculture yields } \\
\text { due to cost of fish feed a constraint on growth. }\end{array}$ \\
\hline Milk/Dairy & 2.0 million & 0.6 million & $\begin{array}{l}\text { Driven by insufficient milking cows and low yields (15- } \\
25 \text { liters/day versus norm of 35-40 liters NZ/US). }\end{array}$ \\
\hline Tomato & 2.2 million & 0.8 million & $\begin{array}{l}\text { Actual production is } 1.5 \text { million tons but } 0.7 \mathrm{M} \text { ton is lost } \\
\text { post-harvest. }\end{array}$ \\
\hline Yams & 39 million & 37 million & $\begin{array}{l}\text { Limited gap today but volumes expected to rise in } \\
\text { planning period. }\end{array}$ \\
\hline Oil Palm & 8.0 million & 4.5 million & $\begin{array}{l}\text { Refers to fresh fruit bunch (FFB) from which oil is } \\
\text { extracted at a } 10 \%-15 \% \text { efficiency rate. }\end{array}$ \\
\hline Cocoa & 3.6 million & 0.25 million & $\begin{array}{l}\text { Demand is global demand which will rise to } 4.5 \mathrm{M} \mathrm{BY} \\
2020 \text {. }\end{array}$ \\
\hline Cotton & 0.7 million & 0.2 million & $\begin{array}{l}\text { Demand is for seed cotton and could rise to } 1.0-1.5 \\
\text { million tons subject to textile sector revival. }\end{array}$ \\
\hline Sorghum & 7.0 million & 6.2 million & $\begin{array}{l}\text { Demand will rise further as use in feed grows in 2016- } \\
2020 \text {. Import of malt extracts and glucose syrup is } \\
\text { currently use to manage gap, hence a commercial threat } \\
\text { for Nigerian farmers. }\end{array}$ \\
\hline
\end{tabular}

Source (FMARD Agriculture Promotion Policy Document, 2016)

Table 2: Selected Countries with Existing Stockpiling Policies and Types of Stocks Maintained

\begin{tabular}{|c|c|c|c|c|c|}
\hline Entity & Country & $\begin{array}{c}\text { Food } \\
\text { Security } \\
\text { Stockpiles }\end{array}$ & $\begin{array}{c}\text { Emergency/Humanitarian } \\
\text { Stocks }\end{array}$ & $\begin{array}{l}\text { Safety Net } \\
\text { Stockpiles }\end{array}$ & $\begin{array}{c}\text { Stockpile for } \\
\text { Export } \\
\text { Purposes } \\
\end{array}$ \\
\hline \multirow[t]{10}{*}{$\begin{array}{l}\text { Country } \\
\text { level }\end{array}$} & China & $\begin{array}{l}\text { Rice, wheat, } \\
\text { corn, soya, } \\
\text { sugar }\end{array}$ & & & \\
\hline & Japan & $\begin{array}{l}\text { Rice, soybean, } \\
\text { wheat }\end{array}$ & $\begin{array}{l}\text { Rice porridge, and other } \\
\text { emergency food supplies }\end{array}$ & & \\
\hline & India & Rice, wheat & Rice and wheat & $\begin{array}{l}\text { Rice and } \\
\text { wheat }\end{array}$ & Rice* \\
\hline & Bangladesh & Rice & & & \\
\hline & Indonesia & $\begin{array}{l}\text { Rice, frozen } \\
\text { beef* }\end{array}$ & Rice & Rice & \\
\hline & Philippines & $\begin{array}{l}\text { Rice, corn, } \\
\text { sugar }\end{array}$ & Rice & & Corn* \\
\hline & Malaysia & Rice & & & \\
\hline & Thailand & & & & Rice, cassava \\
\hline & Singapore & Rice & & & Rice \\
\hline & Vietnam & Soybean* & & & \\
\hline $\begin{array}{l}\text { Regional } \\
\text { level }\end{array}$ & $\begin{array}{l}\text { APTERR } \\
\text { SAARC } \\
\text { ECOWAS }\end{array}$ & $\begin{array}{l}\text { Rice } \\
\text { Rice } \\
\text { Rice } \\
\end{array}$ & & & \\
\hline
\end{tabular}


Table 3: Agricultural Commodities Proposed for Public Stockpiles in Nigeria

\begin{tabular}{|c|c|c|c|c|}
\hline $\mathbf{S} / \mathbf{N}$ & Types of Stock & Objectives & $\begin{array}{c}\text { Types of } \\
\text { Commodities }\end{array}$ & Performance Variables \\
\hline 1. & Food Security & $\begin{array}{l}\text { Ensure food } \\
\text { availabilities }\end{array}$ & $\begin{array}{l}\text { Rice, Corn, Sorghum, } \\
\text { Wheat }\end{array}$ & \\
\hline 2. & $\begin{array}{l}\text { Emergency/Humanitarian } \\
\text { Stocks }\end{array}$ & & & \\
\hline 3. & Buffer Stock Programme & $\begin{array}{l}\text { To stabilise } \\
\text { commodity prices } \\
\text { and help } \\
\text { producers from } \\
\text { price drops and } \\
\text { consumers from } \\
\text { price hike. }\end{array}$ & Cotton, Cocoa, Tea & $\begin{array}{l}\text { Reduce price volatility. } \\
\text { Increase producer prices. } \\
\text { Decrease consumer prices. }\end{array}$ \\
\hline 4. & Social Safety Net Stock & $\begin{array}{l}\text { To provide social } \\
\text { safety net stocks } \\
\text { for impoverished } \\
\text { and chronically } \\
\text { food increase. }\end{array}$ & $\begin{array}{l}\text { Grains (Rice and } \\
\text { Sorghum) }\end{array}$ & $\begin{array}{l}\text { Improvement in food } \\
\text { security indicators } \\
\text { - } \\
\text { Reduce price volatility } \\
\text { Decrease consumer prices. }\end{array}$ \\
\hline 5. & $\begin{array}{l}\text { Stockpile for Export } \\
\text { purposes }\end{array}$ & & $\begin{array}{l}\text { Grains, } \quad \text { Spices, } \\
\text { Leather products, } \\
\text { Cocoa }\end{array}$ & $\begin{array}{l}\text { - For foreign exchange } \\
\text { earnings } \\
\text { - To control quality of } \\
\text { exports. }\end{array}$ \\
\hline
\end{tabular}

Table 4: Percentage (\%) Capacity Utilization by Sectors

\begin{tabular}{|c|c|c|c|c|c|c|c|c|c|c|c|c|}
\hline & \multicolumn{2}{|c|}{2010} & \multicolumn{2}{|c|}{2011} & \multicolumn{2}{|c|}{2012} & \multicolumn{2}{|c|}{2013} & \multicolumn{2}{|c|}{2014} & \multicolumn{2}{|c|}{2015} \\
\hline Sectorial Groups & $\begin{array}{l}1^{\text {st }} \\
\text { Half }\end{array}$ & $\begin{array}{l}2^{\text {nd }} \\
\text { Half }\end{array}$ & $\begin{array}{c}1^{\text {st }} \\
\text { Half }\end{array}$ & $\begin{array}{c}2^{\text {nd }} \\
\text { Half }\end{array}$ & $\begin{array}{c}1^{\text {st }} \\
\text { Half }\end{array}$ & $\begin{array}{l}2^{\text {nd }} \\
\text { Half }\end{array}$ & $\begin{array}{c}1^{\text {st }} \\
\text { Half }\end{array}$ & $\begin{array}{l}2^{\text {nd }} \\
\text { Half }\end{array}$ & $\begin{array}{c}1^{\text {st }} \\
\text { Half }\end{array}$ & $\begin{array}{c}2^{\text {nd }} \\
\text { Half }\end{array}$ & $\begin{array}{l}1^{\text {st }} \\
\text { Half }\end{array}$ & $\begin{array}{l}2^{\text {nd }} \\
\text { Half }\end{array}$ \\
\hline $\begin{array}{l}\text { Food, Beverage } \\
\text { and Tobacco }\end{array}$ & 48.39 & 40.3 & 50.06 & 53.96 & 56.7 & 52 & 53.5 & 61.5 & 53.3 & 52.41 & 54.4 & 52 \\
\hline $\begin{array}{l}\text { Textile Apparel } \\
\text { \& Footwear }\end{array}$ & 38.28 & 20 & 45.17 & 54.22 & 46.7 & 50.8 & 37.4 & 44.9 & 43.5 & 56.18 & 52.7 & 58 \\
\hline $\begin{array}{l}\text { Wood \& Wood } \\
\text { Products }\end{array}$ & 56.56 & 63.3 & 52.0 & 49.3 & 48.2 & 39.4 & 42.3 & 44.4 & 6.0 & 63.64 & 55.3 & 53 \\
\hline $\begin{array}{lr}\text { Pulp, } & \text { Paper, } \\
\text { Printing } & \& \\
\text { Publishing } & \\
\end{array}$ & 42.87 & 63.8 & 48.21 & 52.93 & 53.7 & 49.5 & 52.3 & 60.0 & 60.5 & 53.13 & 52.8 & 56 \\
\hline $\begin{array}{l}\text { Chemical \& } \\
\text { Pharmaceutical }\end{array}$ & 44.77 & 63.8 & 48.21 & 52.93 & 52 & 50.8 & 46.6 & 53.6 & 49.0 & 43.88 & 49.8 & 42 \\
\hline $\begin{array}{l}\text { Non-Metallic } \\
\text { Products } \\
\end{array}$ & 45.64 & 47.9 & 51.11 & 50.38 & 58.2 & 51.8 & 53.8 & 69.9 & 49.2 & 71.03 & 42.7 & 42 \\
\hline $\begin{array}{l}\text { Domestic / } \\
\text { Industrial Plastics } \\
\text { \& Rubber }\end{array}$ & 55.02 & 59 & 49.37 & 51.36 & 49.6 & 51.1 & 51.7 & 59.5 & 52.4 & 55.81 & 51.1 & 37 \\
\hline $\begin{array}{l}\text { Electrical } \quad \& \\
\text { Electronics }\end{array}$ & 43.6 & 29.3 & 42.82 & 46.06 & 40 & 44.7 & 42.9 & 38.6 & 50.4 & 48.3 & 55.6 & 49 \\
\hline $\begin{array}{l}\text { Basic Metal, Iron } \\
\& \text { Steel }\end{array}$ & 43.31 & 50.3 & 44.19 & 41.53 & 46.4 & 40.2 & 45.5 & 52.3 & 49.9 & 46.44 & 50.3 & 53 \\
\hline $\begin{array}{l}\text { Motor Vehicle \& } \\
\text { Misc. Assembly }\end{array}$ & 38.61 & 55.7 & 47.07 & 43.98 & 38.7 & 35.7 & 37.1 & 42.7 & 50.3 & 51.6 & 42.3 & 52 \\
\hline AVERAGE & 45.7 & 47.5 & 47.75 & 48.93 & 49 & 46.6 & 46.3 & 52.7 & 53.3 & 52.41 & 54.4 & 52 \\
\hline
\end{tabular}

Source: Manufacturers Association of Nigeria (MAN) Surveys 
Table 5: Sourcing of Local Raw Materials in Percentage (\%) by Sectors

\begin{tabular}{|c|c|c|c|c|c|c|c|c|c|c|c|c|}
\hline & \multicolumn{2}{|c|}{2010} & \multicolumn{2}{|c|}{2011} & \multicolumn{2}{|c|}{2012} & \multicolumn{2}{|c|}{2013} & \multicolumn{2}{|c|}{2014} & \multicolumn{2}{|c|}{2015} \\
\hline Sectorial Groups & $\begin{array}{c}1^{\text {st }} \\
\text { Half }\end{array}$ & $\begin{array}{l}2^{\text {nd }} \\
\text { Half }\end{array}$ & $\begin{array}{c}1^{\text {st }} \\
\text { Half }\end{array}$ & $\begin{array}{c}2^{\text {nd }} \\
\text { Half }\end{array}$ & $\begin{array}{c}1^{\text {st }} \\
\text { Half }\end{array}$ & $\begin{array}{c}2^{\text {nd }} \\
\text { Half }\end{array}$ & $\begin{array}{c}1^{\text {st }} \\
\text { Half }\end{array}$ & $\begin{array}{l}2^{\text {nd }} \\
\text { Half }\end{array}$ & $\begin{array}{c}1^{\text {st }} \\
\text { Half }\end{array}$ & $\begin{array}{c}2^{\text {nd }} \\
\text { Half }\end{array}$ & $\begin{array}{c}1^{\text {st }} \\
\text { Half }\end{array}$ & $\begin{array}{l}2^{\text {nd }} \\
\text { Half }\end{array}$ \\
\hline $\begin{array}{l}\text { Food, Beverage and } \\
\text { Tobacco }\end{array}$ & 66.28 & 73.8 & 65.03 & 66.36 & 69.49 & 70.74 & 68.99 & 79.34 & 62.4 & 69.75 & 64.73 & 70.32 \\
\hline $\begin{array}{l}\text { Textile Apparel \& } \\
\text { Footwear }\end{array}$ & 29.71 & 30 & 30.67 & 24.61 & 34.46 & 47.22 & 52.86 & 60.79 & 45.8 & 42.00 & 36.75 & 36.25 \\
\hline Wood \& Wood Products & 62.78 & 52.5 & 40.47 & 55.4 & 50 & 46.05 & 53.83 & 61.90 & 52.7 & 57.64 & 43.33 & 63.33 \\
\hline $\begin{array}{l}\text { Pulp, Paper, Printing \& } \\
\text { Publishing }\end{array}$ & 62.0 & 56.7 & 55.27 & 49.9 & 44.41 & 52.24 & 53.13 & 61.10 & 48.3 & 49.64 & 32.50 & 44.38 \\
\hline $\begin{array}{l}\text { Chemical \& } \\
\text { Pharmaceutical }\end{array}$ & 44.58 & 42.2 & 40.5 & 39.11 & 40.26 & 50.67 & 3.2 & 61.8 & 46.3 & 39.09 & 40.98 & 47.4 \\
\hline Non-Metallic Products & 70.0 & 67.9 & 83.95 & 81.5 & 79.29 & 63.16 & 79.55 & 91.48 & 69.6 & 65.33 & 61.36 & 62.25 \\
\hline $\begin{array}{l}\text { Domestic / Industrial } \\
\text { Plastics \& Rubber }\end{array}$ & 46.82 & 40 & 33.04 & 38.21 & 42.65 & 44.24 & 50.91 & 58.55 & 41.1 & 37.03 & 48.20 & 61.10 \\
\hline Electrical \& Electronics & 33.2 & 66.7 & 39.65 & 32.22 & 30.15 & 41.5 & 28.4 & 32.66 & 39.4 & 35.45 & 37.08 & 38.50 \\
\hline Basic Metal, Iron \& Steel & 48.89 & 53.1 & 51.85 & 54.37 & 58.87 & 50.23 & 55.94 & 64.33 & 54.2 & 7.18 & 67.47 & 71.25 \\
\hline $\begin{array}{l}\text { Motor Vehicle \& Misc. } \\
\text { Assembly }\end{array}$ & 29.65 & 31.1 & 22.2 & 15.9 & 26.06 & 9.72 & 12.54 & 14.42 & 16.3 & 44.00 & 24.09 & 13.33 \\
\hline AVERAGE & 49.1 & 51.4 & 47.7 & 45.76 & 47.56 & 47.57 & 50.93 & 58.58 & 47.6 & 46.71 & 45.65 & 50.81 \\
\hline
\end{tabular}

Source: Manufacturers Association of Nigeria (MAN) Surveys

Table 6: Major Raw Materials required in the Ten Sector of MAN that may be Stockpiled

\begin{tabular}{|c|c|c|c|c|c|c|c|c|c|c|}
\hline $\mathbf{S} / \mathbf{N}$ & Pulp \& Paper & $\begin{array}{l}\text { Wood and } \\
\text { Wood }\end{array}$ & FBT & C\& P & BM & DIPRPF & TWL & NMS & MV & $\mathbf{E E}$ \\
\hline 1. & Long fibre pulp & Veneer & Enzymes & Solvent & Copper Products & $\begin{array}{l}\text { High density } \\
\text { Polyethylene }\end{array}$ & $\begin{array}{l}\text { Long } \\
\text { staple } \\
\text { cotton }\end{array}$ & $\mathrm{TiO}_{2}$ & Mild Steel & Steel sheets \\
\hline 2. & Caustic Soda & Fibre Board & Flavourings & $\begin{array}{l}\text { Linear alkyl } \\
\text { Benzene }\end{array}$ & $\begin{array}{l}\text { Stainless Steel } \\
\text { Ingots and other } \\
\text { products }\end{array}$ & $\begin{array}{l}\text { Low Density } \\
\text { Polypropylene }\end{array}$ & & Dolomite & Carbon Steel & Steel rods \\
\hline 3. & Cartons (Waste paper) & & Spices & Polymer/resin & Zinc bars and rods & Carbon Black & & & $\begin{array}{l}\text { Heat treating } \\
\text { Shaft }\end{array}$ & Capacitors \\
\hline 4. & Newspaper & & & Glycerin & & \begin{tabular}{|l} 
Polypropylene \\
\end{tabular} & & & Cast Iron & \\
\hline 5. & & & & Fatty alcohols & & \begin{tabular}{|l|} 
Polyethylene \\
\end{tabular} & & & Aluminum alloys & \\
\hline 6. & & & & Crude palm oil & & $\begin{array}{l}\text { Toluene } \\
\text { Disocynate }\end{array}$ & & & Copper alloys & \\
\hline 7. & & & & $\begin{array}{l}\text { Ultra-fine calcium } \\
\text { carbonate }\end{array}$ & & Zinc Oxide & & & Zinc alloy & \\
\hline 8. & & & & Caustic soda & & & & & Lead alloy & \\
\hline 9. & & & & $\begin{array}{l}\text { Pharmaceutical } \\
\text { active materials }\end{array}$ & & & & & & \\
\hline
\end{tabular}

RMRDC (2018): The National Strategy for Consumption in Raw Material and Products Development 